\author{
D. Bugai ${ }^{1 *}$, A. Skalskyy ${ }^{1}$, K. Haneke ${ }^{2}$, S. Thierfeldt ${ }^{2}$, O. Nitzsche ${ }^{2}$, A. Tretyak ${ }^{3}$, Yu. Kubko ${ }^{1}$ \\ ${ }^{1}$ Institute of Geological Sciences, National Academy of Sciences of Ukraine, Kyiv, Ukraine \\ ${ }^{2}$ Brenk Systemplanung GmbH, Aachen, Germany \\ ${ }^{3}$ SSE "Central Enterprise for Radioactive Waste Management”, Chornobyl, Ukraine
}

*Corresponding author: dmitri.bugai@igs-nas.org.ua

\title{
GROUNDWATER MONITORING AND MODELLING OF THE "VECTOR" SITE FOR NEAR-SURFACE RADIOACTIVE WASTE DISPOSAL IN THE CHORNOBYL EXCLUSION ZONE
}

Results of purposeful groundwater monitoring and modelling studies are presented, which were carried out in order to better understand groundwater flow patterns from the "Vector" site for near-surface radioactive waste disposal and storage in the Chornobyl exclusion zone towards river network. Both data of observations at local-scale monitoring well network at "Vector" site carried out in 2015 - 2016 and modelling analyses using the regional groundwater flow model of Chornobyl exclusion zone suggest that the groundwater discharge contour for water originating from "Vector" site is Sakhan River, which is the tributary to Pripyat River. The respective groundwater travel time is estimated at $210-340$ years. The travel times in subsurface for ${ }^{90} \mathrm{Sr},{ }^{137} \mathrm{Cs}$, and transuranium radionuclides (Pu isotopes, $\left.{ }^{241} \mathrm{Am}\right)$ are estimated respectively at thousands, tenths of thousands, hundreds of thousands - million of years. These results, as well as presented data of analyses of lithological properties of the geological deposits of the unsaturated zone at "Vector" site, provide evidence for good protection of surface water resources from radioactivity sources (e.g., radioactive wastes) to be disposed in the near-surface facilities at "Vector" site.

Keywords: Chornobyl exclusion zone, radioactive waste management, groundwater modelling, risk assessment.

\section{Introduction}

Current strategy for managing radioactive wastes in Ukraine foresees construction of the "Vector" complex in Chornobyl exclusion zone (ChEZ) with a number of facilities for near-surface disposal (short lived wastes), storage (long-lived and high-level wastes, disused sources) and treatment or radioactive wastes. The project design and construction works for "Vector" complex encompass already the period of 30 years. First governmental decision on creation of "Vector" complex was taken in 1987 (initially for wastes of Chornobyl accident origin) by the Government of USSR. The first feasibility study for "Vector" was approved in 1990, while construction of "Vector" started in 1998. At present time a number of facilities are licensed and operating at "Vector", in particular the Engineered Near-Surface Disposal Facility (ENSDF) for solid radioactive waste for disposal of waste packages from the Chornobyl Nuclear Power Plant (ChNPP) Liquid Radioactive Waste Treatment Plant (LRTP) and Solid Radioactive Waste Treatment Plant (SRTP); some facilities are undergoing test exploitation, e.g. Centralized Storage for Disused Sealed Sources (CSDSS), while some other objects are still in process of construction and licensing, e.g. nearsurface disposal facilities for Solid Radioactive Waste of type 1 and 2 (SRW-1 and -2).

The "Vector" complex occupies the area of about $160 \mathrm{ha}$, and it is located $15 \mathrm{~km}$ south-west from ChNPP in the elevated (absolute surface elevations 140 - $145 \mathrm{~m}$ a.s.1.) forested water divide area of
Pripyat River and Uzh River - within the so called Chistogalovka moraine ridge (Fig. 1).

Geological section at the site is composed of Quaternary fluvioglacial and alluvial deposits with the total thickness of about $60 \mathrm{~m}$, mainly consisting of fluvioglacial and alluvial fine-to medium-grained sands, with intermediate loam lenses (moraine) with a thickness of up to $4 \mathrm{~m}$. Below is located the clay marl layer composed of marine deposits of Buchak and Kanev suite of Eocene. The upper soil layers to a depth of about $15 \mathrm{~m}$ below surface (unsaturated zone) are composed of alternating layers of fluvioglacial and moraine deposits represented by fine-grained sands with beds of loam and silt deposits [1]. The Quaternary deposits host the unconfined aquifer with the total saturated thickness of $40-45 \mathrm{~m}$, which is recharged by atmospheric precipitations. The depth to water table at the site ranges from about 15 to $21 \mathrm{~m}$.

Groundwater flow direction from the "Vector" site towards river network were recently a subject of discussion and controversy among hydrogeologists. Two alternative opinions on this subject were stated: (1) groundwater from the site flows towards Pripyat River, or (2) groundwater from the site flows towards Uzh River. Little data were available until now to resolve the above discussion, as groundwater monitoring studies has not been carried out regularly at the existing local-scale monitoring well network at "Vector" site. In addition, the regional level groundwater monitoring network in ChEZ is insufficient for accurately estimating groundwater flow directions from "Vector". 


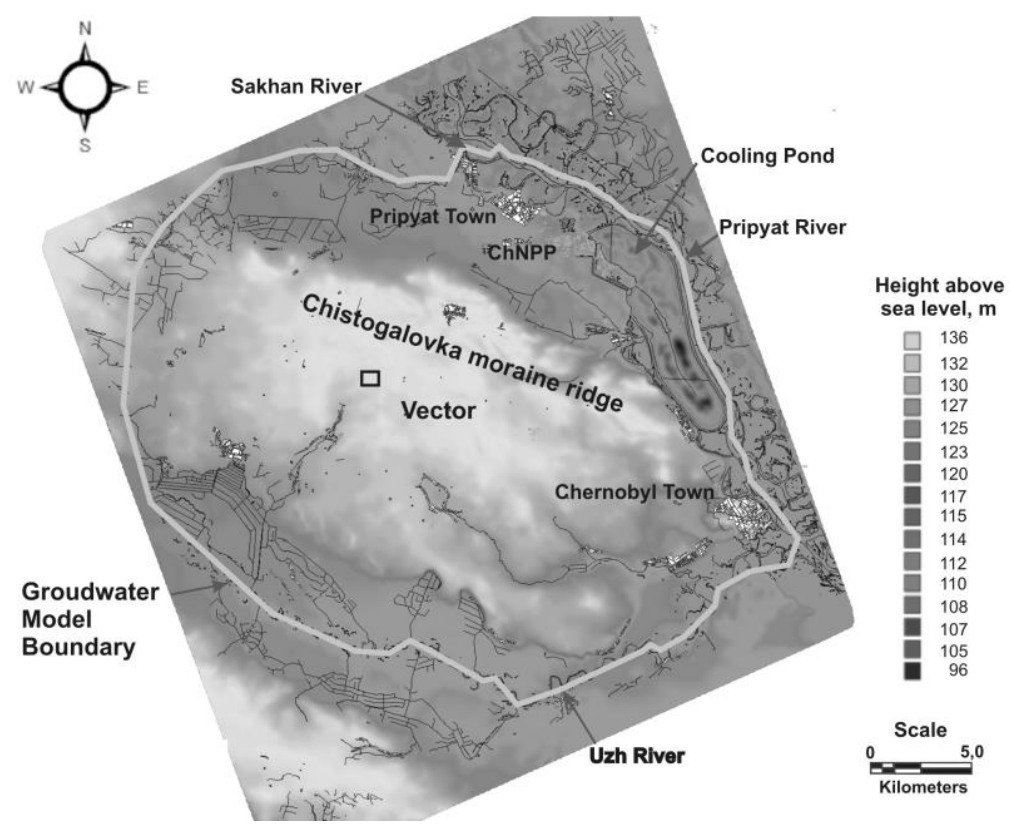

Fig. 1. Topographical map of ChEZ showing location of "Vector" site and the boundary of domain encompassed by groundwater flow model.

Understanding groundwater flow patterns from "Vector" site is important for safety assessment analyses of existing and planned radioactive waste disposal and storage facilities, in particular for assessing of risks of contamination of river network due to radionuclide leaching to groundwater from radioactivity sources at "Vector" site. The aim of the studies presented in this article is to analyse groundwater flow patterns at "Vector" site in the context of regional hydrogeological settings of the $\mathrm{ChEZ}$, and to estimate groundwater flow directions as well as groundwater (and/or radionuclide) travel times in groundwater from "Vector" site to relevant surface water bodies representing the groundwater discharge contours.

The methods used include experimental hydrogeological studies (groundwater monitoring, hydra- ulic tests, laboratory analyses on collected samples of geological deposits), as well as groundwater modelling. The reported studies were carried in a frame of the project with the more broad scope on comprehensive safety assessment of the "Vector" site and other radioactive waste disposal and storage sites situated within the ChEZ (see Acknowledgments to this article).

\section{Experimental hydrogeological studies \\ Groundwater monitoring studies}

Throughout the long period of design and construction of "Vector" complex large number of monitoring wells were constructed at the site, which were related to site characterization works and construction of different radioactive waste disposal and storage facilities (Fig. 2).

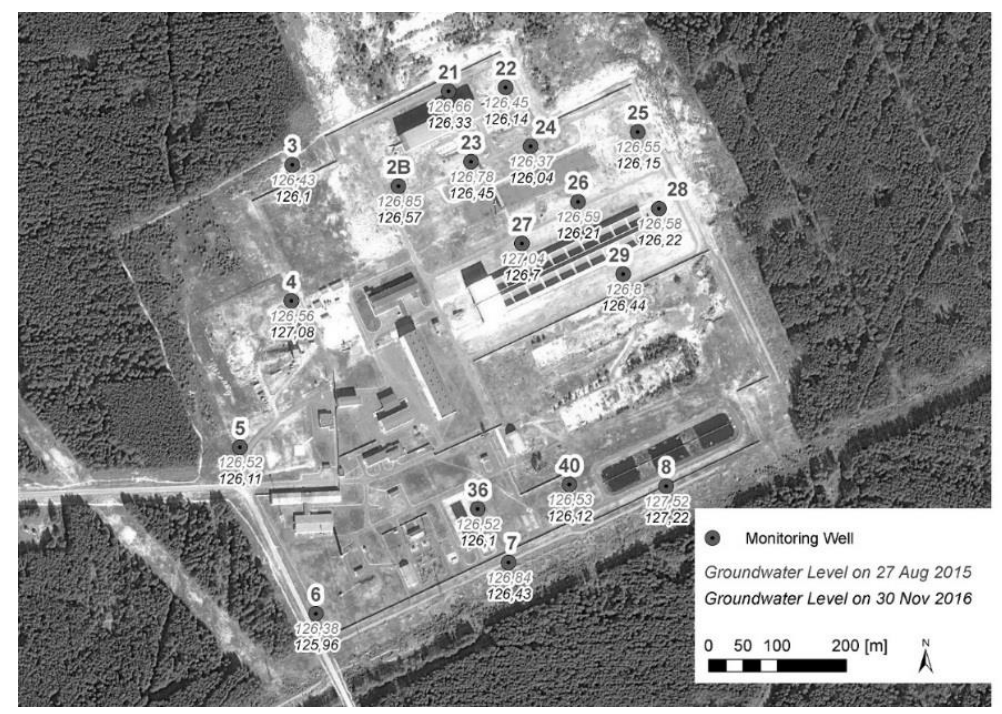

Fig. 2. Layout of "Vector" site with groundwater monitoring system. 
However as most of the facilities are still not licensed and operating, the majority of these wells are not included to the regular monitoring program. Moreover, for many wells passports have been lost during the 30-year long site history, and their technical characteristics were not known precisely.

The authors of this report in collaboration with the Site Operator (Central Enterprise for Radioactive Waste Management - CERWM) have completed in August 2015 and November 2016 first systematic groundwater level surveys at "Vector" site incorporating all available monitoring wells. In the course of these surveys the technical characteristics (e.g., well head elevations, geographical coordinates, depth etc.) were determined and groundwater levels were measured. For several wells with the available passports (i.e., wells situated around the recently commissioned ENDSF facility) hydraulic tests were carried out.

Fig. 3 shows distribution of hydraulic head in wells as a function of well depth. It can be seen that more shallow wells tend to have higher hydraulic head than more deep wells, which indicates groundwater flow direction from upper to deeper strata of the unconfined aquifer. The linear trend suggests that hydraulic head decreases by $\sim 0.12 \mathrm{~m}$ per $1 \mathrm{~m}$ of aquifer depth. Such flow pattern with the large downward vertical gradient of hydraulic head confirms that the "Vector" site is situated in the regional groundwater recharge area. The large value of vertical hydraulic head gradient may be indication of presence sub-horizontal low permeability sediment layers between screens of wells located at different depth in the vertical aquifer cross-section.

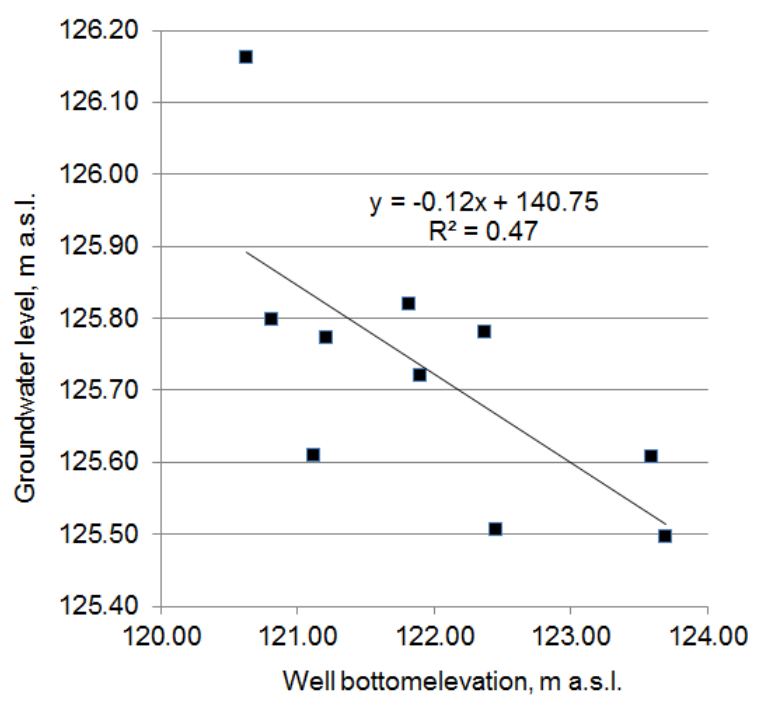

Fig. 3. Hydraulic head in wells at "Vector" site as function of well depth (date 27.08.2015).

In order to determine the direction of groundwater flow in horizontal plane, we have identified a sub-group of wells with the well screen elevations within the approximately the same depth interval (in terms of absolute elevation above the sea level). This was done in order to exclude effects related to vertical gradient of hydraulic head. Next, groundwater table isolines were constructed using groundwater monitoring data for this well subgroup. Example groundwater table plots on 25.08.2015 and 30.11.2016 for a group of wells situated in the northeast part of "Vector" site are shown at Fig. 4. These data clearly show groundwater flow in northeast direction in horizontal plane. Similar flow patterns were observed for both sampling date (27.08.2015 and 30.11.2016) for different well subgroups. The horizontal gradient of hydraulic head for both dates is estimated at $0.005 \mathrm{~m} / \mathrm{m}$.

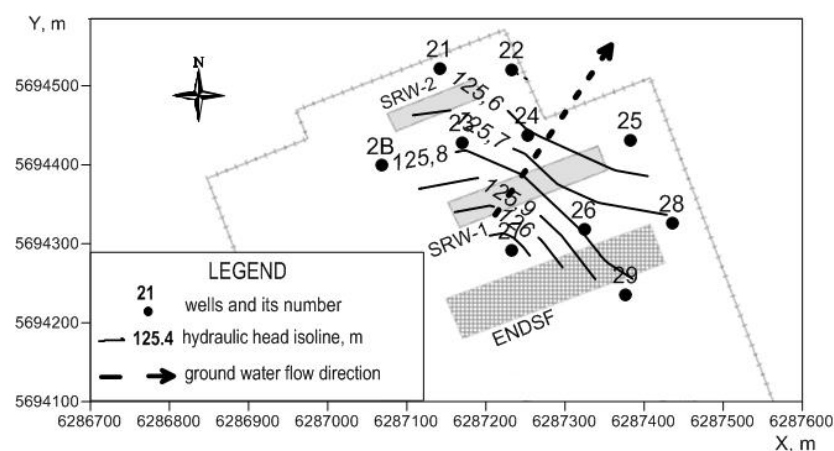

$a$

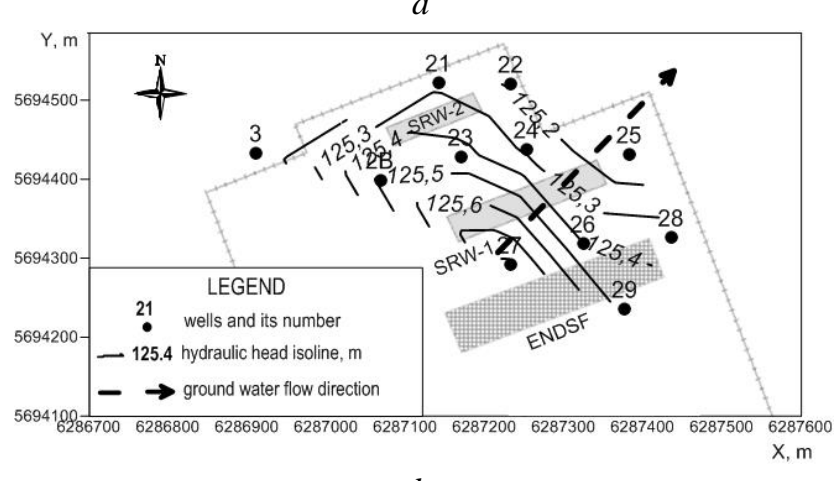

$b$

Fig. 4. Groundwater table at "Vector" site: $a-27.08 .2015 ; b-30.11 .2016$.

\section{Hydraulic testing}

Slug tests have been performed at three monitoring wells at "Vector" site (No. 27, 28 and 29) in July 2015). All these wells have screened interval in the depth range from 20.5 to $23.5 \mathrm{~m}$. During the test a water volume of $8 \mathrm{~L}$ was "instantaneously" added to a well. The changes in water level were subsequently measured with an electronic TD-Diver pressure sensor with the data logger. The interpretation of the collected slug test data using Bouwer-Rice method resulted in hydraulic conductivities of geological deposits as given in Table 1. 
Table 1. Hydraulic conductivity $(\mathbf{K})$ of geological

sediments at "Vector" site based on results of slug tests carried out in August 2015

\begin{tabular}{|c|c|c|c|}
\hline Well No. & 27 & 28 & 29 \\
\hline K, m/day & 0.51 & 0.95 & 1.04 \\
\hline
\end{tabular}

Lithological properties of soils in the unsaturated zone of "Vector" site

In August 2015 a field sampling of Quaternary geological deposits from the unsaturated zone was carried out using the $\sim 9 \mathrm{~m}$ deep sand pit for constructions works situated at about $400 \mathrm{~m}$ to the south of "Vector" site. Sampling was carried at two locations: (1) from the side of the small excavation at pit bottom (samples No. 1 - 4; depths range from 9.2 to $10.7 \mathrm{~m}$ ) and (2) from the upper part of the unsaturated zone from the side of pit (sample No. 5 7 ; depth range from 0 to $2.2 \mathrm{~m}$ ).

The objective was to gain additional information on the local sedimentological conditions, as well as on soil parameters such as grain size distribution, hydraulic conductivity, bulk density, and cationexchange capacity (CEC) (Table 2).

Table 2. Lithological characteristics of soils from the unsaturated zone at "Vector" site

\begin{tabular}{|c|l|l|c|c|c|c|}
\hline $\begin{array}{c}\text { Sample } \\
\text { No. }\end{array}$ & Depth, $\mathrm{m}$ & Lithological description & $\begin{array}{c}\text { Median grain } \\
\text { size }\left(\mathrm{d}_{50}\right), \mathrm{mm}\end{array}$ & $\begin{array}{c}\text { Density, } \\
\mathrm{g} / \mathrm{cm}^{3}\end{array}$ & $\begin{array}{c}\text { Hydraulic } \\
\text { conductivity, m/day }\end{array}$ & $\begin{array}{c}\text { CEC, } \\
\mathrm{meq} / 100 \mathrm{~g}\end{array}$ \\
\hline 1 & $9.2-9.6$ & medium-grained sand & 0.027 & 1.65 & 0.97 & 2 \\
\hline 2 & $9.6-9.85$ & silt, sandy & 0.011 & 1.60 & 0.04 & 4 \\
\hline 3 & $10.85-10.2$ & $\begin{array}{l}\text { medium-fine grained } \\
\text { sand, silty }\end{array}$ & 0.029 & 1.69 & 0.79 & 4 \\
\hline 4 & $10.2-10.7$ & silt, sandy & 0.015 & 1.45 & 0.14 & 6 \\
\hline 5 & $0-1.0$ & $\begin{array}{l}\text { medium-fine grained } \\
\text { sand }\end{array}$ & 0.052 & 1.78 & 1.04 & 2 \\
\hline 6 & $1.0-1.5$ & silt, sandy & 0.023 & 1.63 & 0.07 & 6 \\
\hline 7 & $1.5-2.2$ & $\begin{array}{l}\text { medium-fine grained } \\
\text { sand }\end{array}$ & 0.044 & 1.90 & 0.86 & 4 \\
\hline
\end{tabular}

The main part of laboratory testing was carried out in the laboratories of Institute of Geological Sciences. The CEC analyses were carried out at the Institute of Horticulture in Kyiv using the Bobko Askinazi - Aleshin method.

At both locations alternate deposition of sandy and silty layers of a decimetre thickness range was observed (see Table 2). The results of laboratory tests for samples with sand lithology are in good agreement with the results from field slug tests (see Table 1). The results for CEC show values between 2 and $6 \mathrm{meq} / 100 \mathrm{~g}$ which is characteristic for sandy sediments of predominantly quartz composition with a low content of clay minerals and humic substances. The derived parameters are in general agreement with previous studies [1], but show presence of a smaller scale (e.g., decimetre thickness) sedimentary structures. These data can be used for developing detailed models for radionuclide transport in the unsaturated zone.

\section{Groundwater modelling studies}

Regional groundwater flow model for the ChEZ was developed by the Institute of Geological Sciences since 1986 using, first, electric analogous scheme, and later numerical modelling tools. In 1998 the model was implemented using MODFLOW computer code [2] using Visual Modflow pre-/post-processor software [3]. Since that time the model has been used in numerous research project including optimization of groundwater monitoring system in $\mathrm{ChEZ}$, risk assessment of radioactive waste storage sites, and to simulate the water level drawdown in the cooling pond of ChNPP in the course of its decommissioning [4 - 6]. Detailed description of model is provided in [6].

The groundwater flow model covers the territory of about $30 \times 30 \mathrm{~km}$, bounded by natural hydrological boundaries such as Pripyat, Uzh, Ilya and Sakhan rivers (see Fig. 1). The model encompasses two aquifers belonging to the "zone of active water exchange": - the upper unconfined in QuaternaryNeogene deposits, and lower confined aquifer in Eocene deposits, separated by a low permeability aquitard layer composed of clays and marls of Kyiv suite of Palaeogene. Below the Eocene aquifer is situated the confined aquifer in chalk deposits, which is separated from the Eocene aquifer by a very low conductivity layer of Turonian limestone. Water exchange through this low permeability Turonian aquitard layer can be neglected for modelling purposes [4]. Details on the ChNPP site geology and hydrogeology can be found in $[6,7]$.

The computational grid of the regional model along axes $\mathrm{X}$ and $\mathrm{Y}$ has a variable size. To simulate the "Vector" site, the numerical computational grid of the model was refined in the respective geographical domain. The boundary conditions were 
also précised taking into account the refinements of the numerical grid. The maximum dimension of blocks of computational grid is $250 \times 250 \mathrm{~m}$, while the minimal dimension is $25 \times 30 \mathrm{~m}$.

At the next step the model was calibrated using data of groundwater level observations at "Vector" site and at radioactive waste disposal site (RWDS) Buriakovka. Calibration of groundwater model with respect to groundwater levels in selected observation wells was carried out by fitting the infiltration recharge rate values. In addition, adjusting of the surface water levels in Sakhan and Uzh rivers, as well as in agricultural drainage systems, accounting for grid refinements, was carried out. The result of groundwater model calibration with respect to groundwater levels in observation wells are shown in Fig. 5.

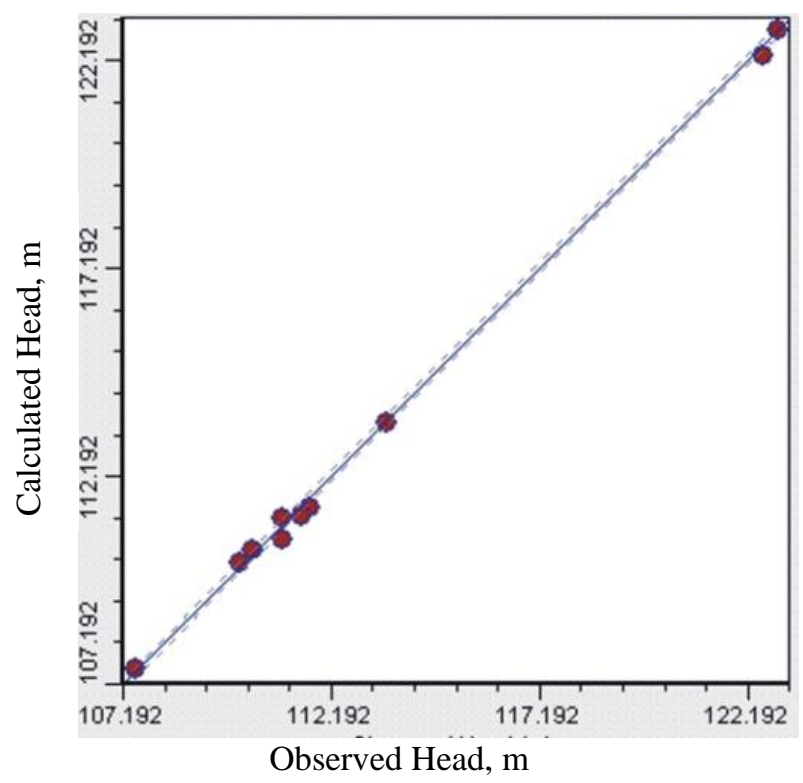

Fig. 5. Groundwater flow model calibration results (calculated vs. observed hydraulic head values in the unconfined aquifer).

The resulting fitted value of the infiltration recharge rate for the area of "Vector" site and
RWDS Buriakovka is $70-80 \mathrm{~mm} / \mathrm{year}$. The calibrated model was used to model groundwater flow for several scenarios of boundary conditions:

hydrogeological boundary conditions following the decommissioning of the Chornobyl cooling pond (i.e., the current day conditions);

hydrogeological boundary conditions after water level drawdown in the cooling pond and full decommissioning of ChNPP (long-term prospective conditions). This last scenario assumes stopping of functioning of the hydro-technical objects belonging to the infrastructure of ChNPP, such as water wells exploiting aquifer in Eocene deposits, facility for treatment and infiltration of sewage water ("filtration fields"), technical drainage systems of ChNPP etc.

Simulations have shown, that following the full decommissioning of the ChNPP significant changes in the hydrogeological conditions occur in the immediate vicinity of the cooling pond, at the industrial site of ChNPP. However, any noticeable impact will be observed from decommissioning of ChNPP on hydrogeological conditions in the area of "Vector" site (as well as RWDS Buriakovka) which are situated at the large distance from the cooling pond and from ChNPP industrial site.

The numerical simulations have shown that for all scenarios groundwater from "Vector" site is filtrating in subsurface towards Sakhan River. Example groundwater flow path lines from "Vector" site are shown at Fig. 6.

Groundwater travel times of an "ideal tracer" (non-adsorbed particle) and several representative radionuclides $\left({ }^{90} \mathrm{Sr},{ }^{137} \mathrm{Cs},{ }^{241} \mathrm{Am}\right.$ and $\mathrm{Pu}$ isotopes) from the source area ("Vector" site) to the relevant groundwater discharge contour are listed in Table 3. It should be noted that groundwater travel time estimates listed in Table 3 do not account for performance of the engineering barriers on near surface radioactive waste disposal facilities, and do not take into account radioactive contaminant retention in the vadose zone.

Table 3. Estimated groundwater travel times by advective transport from "Vector" site to Sakhan River for different radionuclides for different radionuclides

\begin{tabular}{|c|l|c|c|}
\hline Migrating agent & $\mathrm{Kd}, 1 / \mathrm{kg} *$ & Retardation factor** & Groundwater travel time, years \\
\hline groundwater (no sorption) & - & 1 & $210-340$ \\
\hline${ }^{90} \mathrm{Sr}$ & 5 & 30 & $5800-9400$ \\
\hline${ }^{137} \mathrm{Cs}$ & 20 & 110 & $22600-36600$ \\
\hline $\mathrm{Pu}$ isotopes & 400 & 2100 & $450000-730000$ \\
\hline${ }^{241} \mathrm{Am}$ & 1000 & 5300 & $1120000-1810000$ \\
\hline
\end{tabular}

* Radionuclide Kd-s are selected using data from publications [1, 8].

** Retardation factor is defined as $\mathrm{R}=1+\rho / m \mathrm{Kd}$, where $\rho$ is geologic deposit density and $m$ is porosity. 


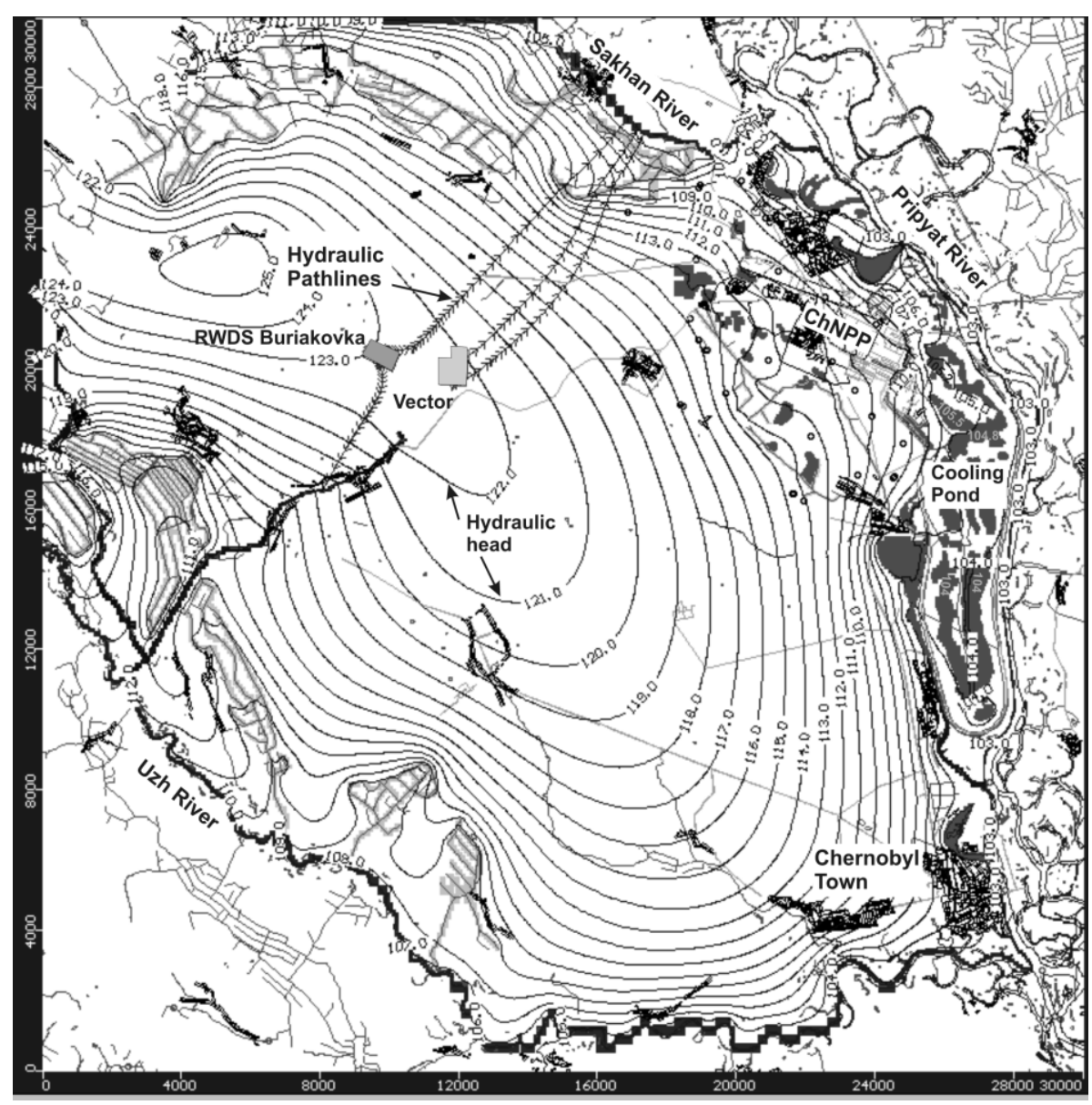

Fig. 6. Simulated regional groundwater flow patterns in the ChEZ for the scenario of decommissioning of the ChNPP (distance between arrow heads of pathlines is 10 years).

According to modelling, even for an ideal ("nonadsorbed") tracer the travel time in groundwater from "Vector" site is estimated at 210 - 340 years. If retardation due to sorption is taken into account, the travel times increase for $\sim 6000$ - 9000 years for ${ }^{90} \mathrm{Sr}$ and several tenths of thousand years for ${ }^{137} \mathrm{Cs}$. Such very long travel times ensure essential decay of these radionuclides during transport process. For $\mathrm{Pu}$ isotopes and ${ }^{241} \mathrm{Am}$ travel times in the subsurface to surface waters are estimated at hundreds thousands millions of years. Such very long travel times may provide potential for radionuclide attenuation due to dispersion, partly irreversible sorption and other and other relevant hydrodynamic and geochemical factors.

\section{Conclusions}

Results of analyses (both monitoring data and modelling results) suggest that groundwater flows from "Vector" site in direction towards Sakhan River, situated within the drainage basin of Pripyat River. The estimated groundwater and radionuclide travel time from "Vector" site to Sakhan River are large (i.e. $210-340$ years) indicating good protection of surface water resources from radioactivity sources (e.g., radioactive wastes) to be disposed (or stored) in the near-surface facilities at "Vector" site.

Presence of silt layers in the unsaturated zone provides generally favourable near-field geology conditions with potential for additional retardation of radionuclides disposed in near-surface facilities.

"Vector" site is situated in the central part of the hydrogeological watershed water-divide area between the Pripyat River and Uzh River. Therefore, modelled groundwater flow directions may be potentially sensitive to changes in the internal and external boundary conditions. In order to determine groundwater flow directions from "Vector" site with a higher certainty, it would be appropriate to extend the regional-scale groundwater monitoring network, and install additional monitoring wells for measuring groundwater levels in locations between "Vector" site and the groundwater discharge contours (i.e., Pripyat and Uzh rivers).

The presented research was supported by the EC technical assistance project to Ukraine INSC Project $\mathrm{U} 4.01 / 10 \mathrm{C}+\mathrm{D}+\mathrm{F}$ "Support of Radioactive waste management in Ukraine", and by the budget theme of the Institute of Geological Sciences of the National Academy of Sciences of the Ukraine No. III-11-14. 


\title{
REFERENCES
}

1. L.M. Shehtman et al. Estimation of protective capacity from radioactive contamination of geological environment at the site of "Vector" complex in the $30-\mathrm{km}$ zone of ChNPP. Problems of Chornobyl exclusion zone. Issue 3 (Kyiv: Naukova Dumka, 1996) 134 (Rus)

2. M.G. McDonald, A.W. Harbaugh. A Modular threedimensional finite-difference ground-water flow model. U.S. Geological Survey Open-File Report 83-875, 1984. 528 p.

3. N. Guiger, T. Franz. User's manual for Visual MODFLOW (Waterloo Hydrogeologic Inc., 1996).

4. A.S. Skalskyy, Y.I. Kubko. Filtration models of the Chornobyl NPP site In: Water Exchange and Chornobyl Accident. Vol. 2. Modeling of water exchange and radionuclide migration in hydrogeology structures. Ed. by V. Shestopalov (Kyiv,
National Academy of Sciences of Ukraine, 2000) p. 448 (Rus)

5. M.J. Buckley et al. Drawing up and evaluating remediation strategies for the Chornobyl cooling pond. Project ref. No. B7-5230/2000/306958/MAR/ C2, NNC Limited, 2002.

6. D. Bugai et al. Geology structure and hydrogeology conditions of the Chornobyl Pilot Site, Report DEI/SARG no.04-16, Institute for Radioprotection and Nuclear Safety, Fontenay aux Roses, 2004.

7. A. Matoshko et al. Sedimentological study of the Chornobyl NPP site to schematize radionuclide migration conditions. Env. Geol. 46 (2004) 820.

8. Handbook of Parameter Values for the Prediction of Radionuclide Transfer in Terrestrial and Freshwater Environments. Technical Reports Series No. 472 (Vienna, International Atomic Energy Agency, 2010).

\section{Д. Бугай ${ }^{1, *}$, О. Скальський ${ }^{1}$, К. Ханеке ${ }^{2}$, С. Тєрфілд², О. Ніцше ${ }^{2}$, О. Третьяк ${ }^{3}$, Ю. Кубко \\ ${ }^{1}$ Інститут геологічних наук НАН Украӥни, Київ, Украӥна \\ ${ }^{2}$ Brenk Systemplanung GmbH, Аахен, Німеччина \\ 3 ДСП "Центральне підприємство з поводження з радіоактивними відходами", Чорнобиль, Украӥна \\ *Відповідальний автор: dmitri.bugai@igs-nas.org.ua \\ МОНІТОРИНГ ПІДЗЕМНИХ ВОД І МОДЕЛЮВАННЯ МАЙДАНЧИКА «ВЕКТОР» ДЛЯ ПРИПОВЕРХНЕВОГО ЗАХОРОНЕННЯ РАДІОАКТИВНИХ ВІДХОДІВ У ЧОРНОБИЛЬСЬКІЙ ЗОНІ ВІДЧУЖЕННЯ}

Наведено результати цільових досліджень із моніторингу підземних вод і моделювання, які було виконано з метою кращого розуміння процесів фільтрації підземних вод від майданчика «Вектор» для приповерхневого захоронення та зберігання радіоактивних відходів у чорнобильській зоні відчуження в напрямку річкової мережі. Як дані спостережень по локальній мережі спостережних свердловин на майданчику «Вектор», що були виконані у 2015 - 2016 рр., так і моделювання за допомогою регіональної фільтраційної моделі чорнобильської зони відчуження вказують, що контуром розвантаження підземних вод, що фільтруються 3 майданчика «Вектор», є р. Сахан - притока р. Прип’ять. Відповідний час фільтрації підземних вод оцінюються в 210 - 340 років. Час міграції підземним шляхом ${ }^{90} \mathrm{Sr},{ }^{137} \mathrm{Cs}$ i трансуранових радіонуклідів (ізотопів плутонію, ${ }^{241} \mathrm{Am}$ ) оцінюється відповідно в тисячі, десятки тисяч, сотні тисяч, мільйон років. Зазначені результати, а також наведені дані дослідження літологічних властивостей геологічних відкладів із ненасиченої зони майданчика «Вектор» свідчать про добру захищеність поверхневих вод від джерел радіоактивності (радіоактивних відходів), що мають бути захоронені у приповерхневих сховищах на майданчику «Вектор».

Ключові слова: чорнобильська зона відчуження, поводження з радіоактивними відходами, моделювання підземних вод, оцінки ризику.

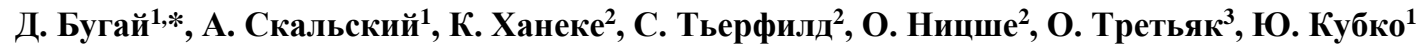 \\ ${ }^{1}$ Институт геологических наук НАН Украинь, Киев, Украина \\ ${ }^{2}$ Brenk Systemplanung GmbH, Аахен, Германия \\ ${ }^{3}$ ГСП «Центральное предприятие по обращению с радиоактивными отходами», Чернобыль, Украина
}

*Ответственный автор: dmitri.bugai@igs-nas.org.ua

\section{МОНИТОРИНГ ПОДЗЕМНИХ ВОД И МОДЕЛИРОВАНИЕ УЧАСТКА «ВЕКТОР» ДЛЯ ПРИПОВЕРХНОСТНОГО ЗАХОРОНЕНИЯ РАДИОАКТИВНІХ ОТХОДОВ В ЧЕРНОБЫЛЬСКОЙ ЗОНЕ ОТЧУЖДЕНИЯ}

Приведены результаты целевых исследований по мониторингу подземных вод и по моделированию, которые были выполнены с целью лучшего понимания процессов фильтрации подземных вод от участка «Вектор» для приповерхностного захоронения и хранения радиоактивных отходов в чернобыльской зоне 
отчуждения в направлении речной сети. Как данные наблюдений по локальной сети наблюдательных скважин на участке «Вектор», которые были выполнены в 2015 - 2016 гг., так и моделирование с использованием региональной фильтрационной модели чернобыльской зоны отчуждения указывают, что контуром разгрузки подземных вод, которые фильтруются от участка «Вектор», является р. Сахан - приток р. Припять. Соответствующее время фильтрации подземных вод оценивается в 210 - 340 лет. Время миграции подземным путем ${ }^{90} \mathrm{Sr},{ }^{137} \mathrm{Cs}$ и трансурановых радионуклидов (изотопов плутония, ${ }^{241} \mathrm{Am}$ ) оценивается соответственно в тысячи, десятки тысяч, сотни тысяч, миллион лет. Указанные результаты, а также приведенные данные изучения литологических характеристик геологических отложений из ненасыщенной зоны участка «Вектор» свидетельствуют о хорошей защищенности поверхностных вод от источников радиоактивности (радиоактивных отходов), которые будут захораниваться в приповерхностных хранилищах на участке «Вектор».

Ключевые слова: чернобыльская зона отчуждения, обращение с радиоактивными отходами, моделирование подземных вод, оценки риска.

Надійшла 19.10.2017

Received 19.10.2017 